\title{
Profile of resident microbes causing spoilage in "olewonyo", a locally produced non-alcoholic beverage in Kumasi, Ghana
}

\author{
M.G. Addo ${ }^{1}$ L.A. Andoh ${ }^{2}$ and K. Obiri-Danso ${ }^{3}$ \\ Dept. of Theoretical and Applied Biology, Kwame Nkrumah University of Science and Technology, Kumasi, Ghana ${ }^{1,2,3}$
}

\begin{abstract}
Samples of olewonyo from two different localities together with a laboratory produced sample were analyzed for microbial changes, $\mathrm{pH}$, titrable acidity and salt tolerance. High total viable counts (TVC) of $9.99 \mathrm{log} \mathrm{cfu} / \mathrm{ml}, 9.23$ $\log \mathrm{cfu} / \mathrm{ml}$ and $5.00 \log \mathrm{cfu} / \mathrm{ml}$ were observed in the Aboabo, Anloga and Lab-simulated samples respectively at room temperature at day 3 (72hours). There was no significant differences in microbial load among the various samples among TVCs, lactic acid bacteria (LAB), lactic-acid cocci, and yeasts and moulds counts as the storage time increases $(\mathrm{p}<0.001)$. The $\mathrm{pH}$ of samples from Aboabo and Anloga showed a rapid decline from 6.55 and 6.60 to 4.55 and 4.30 respectively within 24-hour of storage. The changes in the Lab-produced sample however, showed a gradual decrease from 6.55 to 4.80 for the entire period of storage. There was no significant increase in titrable acidity of the laboratory sample $(\mathrm{p}<0.02)$ compared to the traditional samples. Of the $15 \mathrm{LAB}$ isolates from the three sites, $40 \%$ were Lactobacillus fermentatum, 26.6\% Lactobacillus plantarum, 20\% Lactobacillus acidophilus and $13.4 \%$ Lactobacillus brevis. In the API gallaries, the dominant species were able to ferment ribose, galactose, D-glucose, D-fructose and mannitol. The present study shows that Leuconostoc mesenteroides, Lactobacillus plantarum, L. acidophilus, L. brevis, L. fermentatum, Corynebacterium, Saccharomyces cerevisiae, Aspergillus flavus and A. parasiticus may be involved or associated in the spoilage of olewonyo.
\end{abstract}

Keywords: olewonyo, titrable acidity, lab-simulated, microbial load, spoilage.

\section{INTRODUCTION}

'Olewonyo' or corn wine is a traditional non-alcoholic everage prepared from maize (Zea mays). It is dark-brown in colour with sweet taste and is consumed locally in Ghana and Togo. Different ethnic groups have different names. In Ghana, the Akans call it 'Olewonyo', the Ewes call it 'Aliha' whilst the Gas refer to it as 'Asaana'.

Many such traditional beverage products are home to a complex microbial ecosystem, which is responsible for the broad diversity of tastes, aromas, and textures that are associated with them [1]. Many bacteria make a positive contribution to the organoleptic qualities of both fermented and non-fermented beverages, while others may have adverse effects or may even constitute a health risk. Deak and Beuchat [2] reported that, the beneficial activities of yeasts and microorganisms in general are of great economic significance and they have been used for millennia in the production of fermented foods and alcoholic beverages.

It is again reported that, lactic acid bacteria (LAB) enhance cheese flavor and diversity [3]. These LAB are characterized by a succession of largely undefined microbial communities on their surface and have a strong impact on the appearance, odor, flavor and texture development of respective products [4]. There is a growing interest in the biodiversity and ecology of microorganisms associated with different foods [5]. This is due to the realization that they can interact with themselves and other species in different ecosystems and that the outcome of these interactions may affect the role(s) that microorganisms have in foods.
Traditionally, 'olewonyo' preparation is a batch process carried out on a small scale, once or twice a week. The grains are consistently sprinkled with water and spread on fiber sacks and allowed to germinate. The germinated grains are left in the sun for 2 days to dry. The malted grains are then coarse grounded and mixed with water and boiled for an hour till it is cooked. The cooked drink is left overnight to allow particles to settle. The supernatant is then decanted and brown sugar is added to the creamy supernatant which gives the drink its characteristic brown colour and the sweet taste.

Olewonyo, like many other traditional foods and beverages are prepared in small scale in the village homes. Their quality therefore depends on the skills of the households, as inherited over the years. The drink and its production add value and significance to the Ghanaian culture and economy. It is served chilled in the villages as soft drinks during festive occasions and now, as a source of income to some low income women who produce them and go round the big markets in the cities to sell them in very big calabashes and pots.

While there have been several studies on the microbial composition of these [6-8], little is known on the diversity of yeasts and other microorganisms associated with these foods. The mode of production makes this non-alcoholic beverage prone to microbial contaminations, hence, its short shelf-life of one to maximum three days.

In view of the slight differences in methodology on the skills of the producers in the preparation and the environmental conditions in its production which affects 
its shelf-life, there is the need to conduct a detailed study to isolate and characterize the resident microbial profile in 'olewonyo' and determine their role in the spoilage of the drink.

\section{MATERIALS AND METHODS}

\section{A. Sample collection}

Traditional olewonyo samples were obtained from two different local markets in Aboabo and Anloga which are all suburbs of Kumasi, the regional capital of Ashanti, Ghana. A third sample was prepared in the laboratory under aseptic conditions. The raw materials (maize) used in preparation of the drink were bought at a local market in the study areas and divided into three batches. Two of the batches were used for traditional preparation, while the third batch was used for the laboratory study at the Microbiology Laboratory of the Department of Theoretical and Applied Biology, Kwame Nkrumah University of Science and Technology, Kumasi, Ghana.

For the traditional processing, the materials were given to six randomly selected local women experienced in preparation of olewonyo (three in each of the localities). They were requested to prepare the product using the traditional method. Households with women experienced in the art of olewonyo preparation were selected and the numbers randomized by the calculator random method.

The samples from the women were collected in sterile sample containers, cooled to $4^{\circ} \mathrm{C}$ and transported to the laboratory in a cool box containing freeze packs to maintain them at the temperature between collection and analysis. The samples were again divided into two batches and stored at room temperature $\left(25^{\circ} \mathrm{C}\right)$ and refrigeration temperature $\left(4^{\circ} \mathrm{C}\right)$. The sample from the laboratorysimulated production were also maintained at $4^{\circ} \mathrm{C}$ and $25^{\circ} \mathrm{C}$ prior to the microbiological analysis.

\section{B. Analytical methods}

During the preparation of olewonyo from the traditional sites and the laboratory, samples were taken at 24-hour intervals for Total Viable Counts (TVCs), Lactic acid bacteria (LAB - lactococci and lactobacillus), yeasts and moulds counts and total coliforms. On the other hand, samples were taken at 12-hour intervals for the analysis of $\mathrm{pH}$ and titratable acidity (TA). The $\mathrm{pH}$ was measured using a pH meter (Orion Model 420A). Titratable acidity was determined according to AOAC methods (AOAC, 1984) [9]. A sample of $10 \mathrm{ml}$ was titrated with $0.1 \mathrm{~N}$ $\mathrm{NaOH}$ using phenolphthalein as an indicator. The titratable acidity was calculated as percent lactic acid.

\section{Microbiological analysis}

The methods and procedures used were as described by Harrigan and McCance, [10], FDA, bacteriological analytical manuals (FDA, [11] and ALPHA, compendium of methods for microbiological examination of foods (APHA, 1992). Total viable counts (TVC) were determined using the pour plate method of Harrigan and McCance [10]. Decimal dilutions were made with 0.1 percent bacteriological peptone. One millilitre of the $10^{-8}$ to $10^{-14}$ dilutions was used to prepare pour plates using plate count agar (PCA). The plates were incubated at $30^{\circ} \mathrm{C}$ for $48 \mathrm{hrs}$. The colonies on plates with between 30-300 colonies were counted.

LAB counts were determined using MRS (deMan Rogosa Sharpe) and M17 agar incubated anaerobically at $30^{\circ} \mathrm{C}$ for 3 days. Isolates of Lactic acid bacteria (LAB) were tentatively identified by determining their pattern of carbohydrate fermentation using the API $50 \quad \mathrm{CH}$ (BioMérieux, Marcy-l'Etoile, France) and comparing them to the API database.

The counts of yeasts and moulds were determined using potato dextrose agar (PDA), acidified with $10 \%$ tartaric acid to $\mathrm{pH} 3.5$ by incubating at $30^{\circ} \mathrm{C}$ for $3-5$ days. Coliform numbers were determined using violet red bile glucose agar incubated at $37^{\circ} \mathrm{C}$ for $48 \mathrm{hrs}$.

\section{Salt Tolerance Test and Growth at different $\mathrm{pH}$}

Salt tolerance test was done using MRS (Oxoid CM359) containing $6.5 \%$ and $18 \%(\mathrm{w} / \mathrm{v}) \mathrm{NaCl}$ with incubation period of 4 days at $15^{\circ} \mathrm{C}$ and $45^{\circ} \mathrm{C}$. $\mathrm{pH}$ was adjusted to 4.4 and 9.6. Growth were observed in MRS broth.

\section{E. Statistical analysis of the data}

The data collected was entered in MS Access and MS Excel solver as data base for optimization. The data was analyzed using Genstat 5 Release 3.2 statistical package and Statistical Package for the Social Sciences (SPSS 12.0 for Windows). The data validity and interpretation was monitored to ensure quality control of the results.

\section{RESULTS}

A. Microbial content and changes of olewonyo during storage at room temperature $\left(25^{\circ} \mathrm{C}\right)$.

There was a general increase in microbial numbers in samples of olewonyo stored at room temperature with increasing time of storage.

Table 1 shows the microbial counts in olewonyo during storage. This increase was different for all the samples from Aboabo, Anloga and the laboratory-produced. High total viable counts (TVC) of $9.99 \log \mathrm{cfu} / \mathrm{ml}, 9.23 \mathrm{log}$ $\mathrm{cfu} / \mathrm{ml}$ and $5.00 \log \mathrm{cfu} / \mathrm{ml}$ were observed in the Aboabo, Anloga and Lab-simulated samples respectively at room temperature at day 3 (72hours) with the lactic acid bacteria (LAB) being the predominant microbes. There was no significant differences in microbial load among the various samples between TVCs, LAB, lactic-acid cocci, and yeasts and moulds counts of the traditional and laboratory-simulated products as the storage time increases $(\mathrm{p}<0.001)$.

The results showed that the microbial contents in olewonyo produced in the laboratory, were almost comparable to those of the traditional products. The TVCs were high and continue to increase steadily throughout the storage period. The lactococci showed a fairly constant trend during the storage period with values ranging from $3.45-8.44 \log _{10} \mathrm{CFU} / \mathrm{ml}$. The yeast and moulds counts were relatively constant.

In all cases, the laboratory-simulated samples recorded the least number of microorganisms during the storage period. 
TABLE 1: Mean microbial counts in traditionally and laboratory-simulated olewonyo under different storage temperature.

\begin{tabular}{|c|c|c|c|c|c|c|c|}
\hline \multirow[b]{3}{*}{ Microorganism(s) } & \multirow{3}{*}{$\begin{array}{l}\text { Time } \\
\text { (hrs) }\end{array}$} & \multicolumn{6}{|c|}{$\underline{\text { Microbial Count }\left(\log _{10} \underline{C F U} / \mathrm{ml}\right)}$} \\
\hline & & \multicolumn{2}{|c|}{ Aboabo } & \multicolumn{2}{|c|}{ Anloga } & \multicolumn{2}{|c|}{ Laboratory-simulated } \\
\hline & & $4 \mathrm{C}$ & $25^{\circ} \mathrm{C}$ & $4^{\circ} \mathrm{C}$ & $25^{\circ} \mathrm{C}$ & $4^{\circ} \mathrm{C}$ & $25^{\circ} \mathrm{C}$ \\
\hline \multirow[t]{4}{*}{ Total Viable Count } & $\mathbf{0}$ & 2.41 & 2.41 & 2.71 & 2.71 & 1.82 & 1.82 \\
\hline & 24 & 2.61 & 4.29 & 2.83 & 5.42 & 1.94 & 2.28 \\
\hline & 48 & 2.91 & 7.89 & 4.01 & 7.17 & 2.00 & 4.62 \\
\hline & 72 & 3.22 & 9.99 & 4.62 & 9.23 & 2.96 & 5.00 \\
\hline \multirow{4}{*}{$\begin{array}{l}\text { Lactic acid } \\
\text { bacteria }\end{array}$} & $\mathbf{0}$ & 2.10 & 2.10 & 1.98 & 1.98 & 1.00 & 1.00 \\
\hline & 24 & 2.61 & 4.41 & 2.11 & 4.23 & 1.72 & 1.89 \\
\hline & 48 & 3.91 & 8.20 & 2.90 & 8.40 & 1.75 & 2.41 \\
\hline & 72 & 5.51 & 9.41 & 4.23 & 9.12 & 1.91 & 2.80 \\
\hline \multirow[t]{4}{*}{ Lactic acid cocci } & $\mathbf{0}$ & 1.80 & 1.80 & 1.74 & 1.74 & 1.14 & 1.14 \\
\hline & 24 & 1.94 & 3.91 & 1.88 & 2.61 & 1.80 & 2.61 \\
\hline & 48 & 3.31 & 7.22 & 2.61 & 6.88 & 2.22 & 3.01 \\
\hline & 72 & 4.88 & 8.42 & 4.12 & 8.44 & 2.71 & 3.45 \\
\hline \multirow[t]{4}{*}{ Yeast and moulds } & $\mathbf{0}$ & 1.10 & 1.10 & 1.20 & 1.20 & 0.41 & 0.41 \\
\hline & 24 & 1.21 & 1.40 & 1.92 & 1.54 & 0.48 & 0.61 \\
\hline & 48 & 1.41 & 2.00 & 1.95 & 2.22 & 0.61 & 1.01 \\
\hline & 72 & 1.86 & 2.80 & 1.99 & 2.76 & 0.91 & 1.22 \\
\hline
\end{tabular}

Values are means of 3 replicate

B. Microbial load and changes of olewonyo during storage at room temperature $\left(4^{\circ} \mathrm{C}\right)$

Although there was an increase in the microbial load in samples of olewonyo from all the samples stored at refrigeration temperature $\left(4^{\circ} \mathrm{C}\right)$, they were not as the rate of increase in samples stored at room temperature. The rate followed the same pattern as that of room temperature with total viable counts of $3.22 \mathrm{log} \mathrm{cfu} / \mathrm{ml}, 4.62 \mathrm{log} \mathrm{cfu} / \mathrm{ml}$ and $2.96 \log \mathrm{cfu} / \mathrm{ml}$ for Aboabo, Anloga and Labproduced samples respectively at day 3 (Table 1).

Under this temperature, the predominant microbes were the $\mathrm{LAB}$ and lactic acid cocci. Unlike storage at $25^{\circ} \mathrm{C}$ where Aboabo recorded the highest total viable counts followed by Anloga in the traditional sites, the situation was different at $4^{\circ} \mathrm{C}$. Anloga and Aboabo recorded 4.62 $\log \mathrm{cfu} / \mathrm{ml}$ and $3.22 \log \mathrm{cfu} / \mathrm{ml}$ respectively at day 3 (Table 1). There was no significant difference in microbial load among the various samples $(\mathrm{p}<0.011)$ between TVCs, LAB, lactic-acid cocci, and yeasts and moulds counts between the traditional and laboratory produced products as the storage time increases. The lactococci showed a fairly constant trend during the storage period with values ranging from $2.71-4.88 \log _{10} \mathrm{CFU} / \mathrm{ml}$. The yeast and moulds counts were relatively constant

C. Biochemical changes during olewonyo storage.

The $\mathrm{pH}$, titratable acidity changes and microbial profile were monitored during the storage of olewonyo at a 12hour interval for 60 hours at $4^{\circ} \mathrm{C}$. The changes in $\mathrm{pH}$ and titratable acidity during storage of olewonyo are shown in Figures 1 and 2 respectively. The mean $\mathrm{pH}$ of samples from Aboabo and Anloga showed a rapid decline from an initial value of 6.55 and 6.60 to 4.55 and 4.30 respectively within 24 -hour of storage. This was followed by a steady decline from a $\mathrm{pH}$ of 4.55 and 4.30 to 2.80 and 2.65 in the next 36 hours of storage.

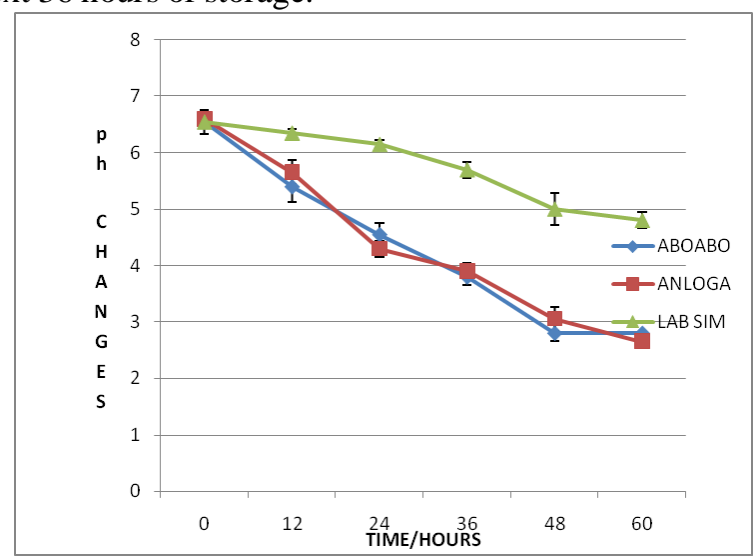

Figure 1: Mean changes in $\mathrm{pH}$ during storage of olewonyo at $4^{\circ} \mathrm{C}$

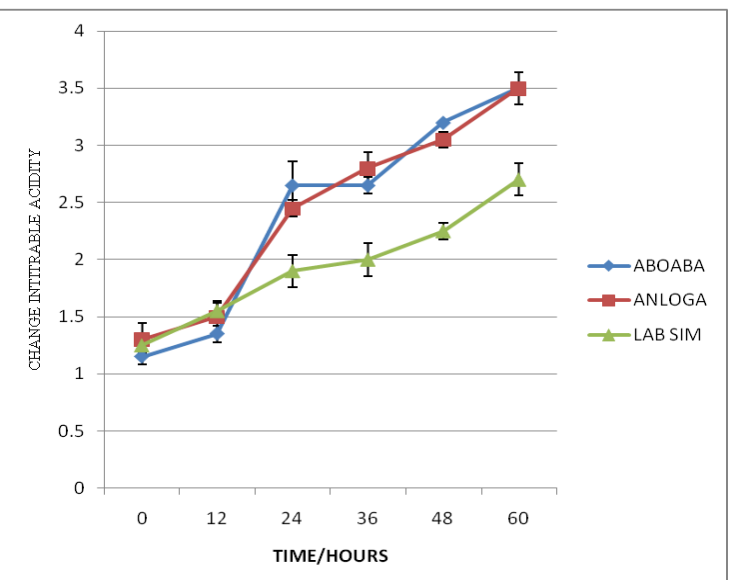

Figure 2: Changes in titratable acidity during storage of olewonyo at $4^{\circ} \mathrm{C}$ 
The changes in the mean $\mathrm{pH}$ of the Lab-produced sample Lactobacillus plantarum on the other hand showed growth however, showed a gradual decrease from 6.55 to 4.80 for at $15^{\circ} \mathrm{C}$ but not at $45^{\circ} \mathrm{C}$. They also showed growth in both the entire period of storage. The titratable acidity of pHs 4.4 and 9.6. In the API gallaries, they were able to samples from Aboabo and Anloga increased from a value ferment ribose, galactose, D-glucose, D-fructose and of 1.15 to 3.50 and 1.30 to 3.50 respectively during mannitol. Two other species identified based on their storage of olewonyo (Figure 2).

Although the laboratory-simulated sample also showed increase in titratable acidity, it was not significant $(\mathrm{p}<0.02)$ as those from the two traditional samples.

D. Biochemical characteristics of lactic acid bacteria isolates in olewonyo using API-50 CH

Out of the 15 lactic acid bacteria isolates from olewonyo from the three sites (five from each site, Table 2), $40 \%$ were Lactobacillus fermentatum, 26.6\% Lactobacillus plantarum, $20 \%$ Lactobacillus acidophilus and $13.4 \%$ Lactobacillus brevis.

The dominant species were able to grow at $45^{\circ} \mathrm{C}$ but not at $15^{\circ} \mathrm{C}$. They also grew in $6.5 \% \mathrm{NaCl}$ and at $\mathrm{pH} 4.4$ and 9.6 (Table 2). biochemical characteristics and pattern of carbohydrate fermentation were Lactobacillus acidophilus and Lactobacillus brevis.

E. Microorganisms isolated from olewonyo samples from the different sites stored at different temperatures.

The laboratory-simulated samples had the lowest number of different species of microorganisms at $4^{\circ} \mathrm{C}$ and $25^{\circ} \mathrm{C}$ respectively (Table 3 ). Aboabo had the highest isolates of 9 at both $4^{\circ} \mathrm{C}$ and $25^{\circ} \mathrm{C}$ while Anloga had 7 and 9 isolates at $4^{\circ} \mathrm{C}$ and $25^{\circ} \mathrm{C}$ respectively. The most frequent species are Lactobacillus plantarum and L. fermentatum. The laboratory-simulated samples did not record $L$. mesenteroides, L. brevis, E. coli and Aspergillus flavus even though they were found in the Aboabo and Anloga samples (Table 3)

TABLE 2: Biochemical characteristics of lactic acid bacteria isolates in olewonyo samples using API-50 CH from the sample sites

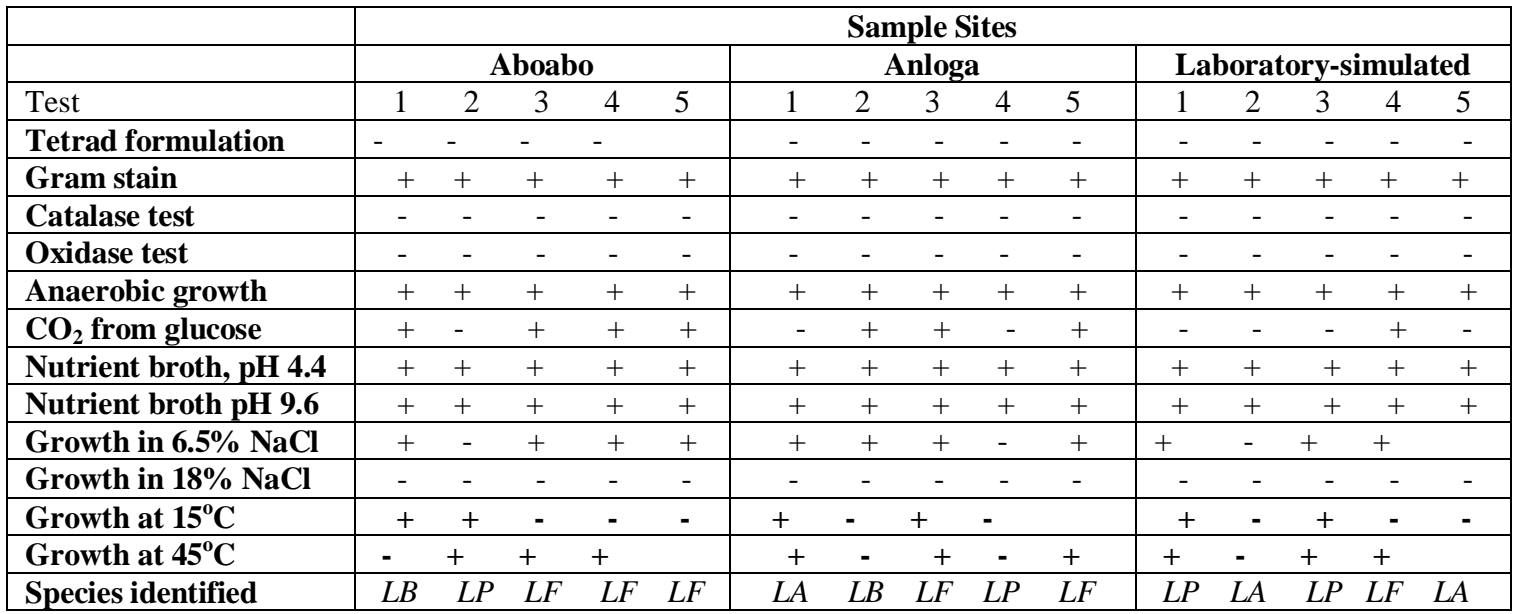

LA - Lactobacillus acidophilus ; LB - Lactobacillus brevis; LF - Lactobacillus fermentatum ; LP - Lactobacillus plantarum

Table 3: Microbial species isolated from olewonyo samples from different sites and stored at different storage temperatures $\left(4^{\circ} \mathrm{C}\right.$ and $\left.25^{\circ} \mathrm{C}\right)$

\begin{tabular}{|c|c|c|c|c|c|c|c|}
\hline \multirow{2}{*}{} & \multicolumn{7}{|c|}{ Sample Sites } \\
\cline { 2 - 7 } & Aboabo & \multicolumn{3}{|c|}{ Anloga } & \multicolumn{2}{c|}{ Lab-sim. } \\
\cline { 2 - 7 } & \multicolumn{5}{|c|}{ Storage Temperature ${ }^{\mathbf{0}}$ C) } \\
\cline { 2 - 7 } & $\mathbf{4}$ & $\mathbf{2 5}$ & $\mathbf{4}$ & $\mathbf{2 5}$ & $\mathbf{4}$ & $\mathbf{2 5}$ \\
\hline Leuconostoc mesenteroides & + & + & + & + & - & - \\
\hline Lactobacillus plantarum & + & + & + & + & + & + \\
\hline Lactobacillus acidophilus & - & - & + & + & + & + \\
\hline Lactobacillus brevis & + & + & + & + & - & - \\
\hline Lactobacillus fermentatum & + & + & + & + & + & + \\
\hline Corynebacterium & + & + & - & + & - & - \\
\hline Saccharomyces cerevisiae & + & + & + & + & - & + \\
\hline Escherichia coli & + & + & - & + & - & - \\
\hline Aspergillus flavus & + & + & + & - & - & - \\
\hline Aspergillus parasiticus & + & + & - & + & - & - \\
\hline Total & $\mathbf{9}$ & $\mathbf{9}$ & $\mathbf{8}$ & $\mathbf{9}$ & $\mathbf{5}$ & $\mathbf{6}$ \\
\hline
\end{tabular}




\section{DISCUSSION}

A. Microbial load and Biochemical changes during storage at $4^{\circ} \mathrm{C}$ and $25^{\circ} \mathrm{C}$.

High microbial load was observed in olewonyo with initial counts of between 1.82-2.71 $\log 10 \mathrm{CFU} / \mathrm{ml}$ at both storage temperatures. The relatively high levels of reducing sugars and sucrose are possibly the reason why there were high counts of LAB. The initial counts increased to high levels of 9.41 and $9.12 \log 10 \mathrm{CFU} / \mathrm{ml}$ for Aboabo and Anloga respectively during the storage period. These figures are similar to microbial counts reported in the Zimbabwean mangisi [12]. It has also been reported that in the preparation of kirario (a Kenyan fermented porridge of the Merus), a microbial load of more than 9.3-9.5 $\log 10 \mathrm{CFU} / \mathrm{ml}$ were recorded [13]. This is very similar to the results in this study. The low $\mathrm{pH}$ of 2.8, 2.6 and 4.8 for Aboabo, Anloga and the Laboratory simulated samples respectively in olewonyo is also in agreement with other cereal based fermented beverages with $\mathrm{pH}$ values in the range of $3.0-4.8$. It is reported that most species of $\mathrm{LAB}$ and acetic acid bacteria (AAB) grow at $\mathrm{pH}$ 3.6-3.8, and some even at $\mathrm{pH}$ 3.0. The recorded low $\mathrm{pH}$ can be attributed to the high lactic acid bacteria (LAB) counts observed in the product. In previous studies, it has been found that the lactococci group of LAB decreases during fermentation as a result of the decrease in $\mathrm{pH}$. . $\mathrm{LAB}$ are known to be able to tolerate environments with low $\mathrm{pH}$. Lawlor et al. [14] reports that LAB typically enter breweries from raw materials and juice ingredients. It is also reported that the lactococci group, especially the Leuconostoc, is less resistant to low $\mathrm{pH}$ than the Lactobacillus.

The gradual decrease in $\mathrm{pH}$ values and increased titrable acidity may be as a result of microbial activity on the carbohydrates to produce organic acids such as lactic acid in the olewonyo from all the sample sites. Namugumya and Muyanja [15] reported that a decreased $\mathrm{pH}$ during the fermentation process could accelerate LAB growth.

B. Microorganisms isolated from olewonyo samples from different sites at different temperatures.

The raw materials and the preparation method used are likely to influence the type of microorganisms involved in the spoilage of olewonyo. The presence of these ten microorganisms other than yeast in olewonyo (Table 3) could lead to faster deterioration of the olewonyo as they are permanently and consistently present in the samples.

Lactobacillus plantarum, L. fermentatum and Saccharomyces cerevisiae were isolated in samples from all the sites and at the two different temperatures. Sawadogo, et al. [16] in their studies on pito production (a locally brewed alcoholic beverage from millet in northern Ghana) reported of $L$. fermentatum as the dominant species during acidification of the product. The presence of $L$. brevis, $L$. acidophilus and Corynebacterium species has also been reported in other traditional beers such as chibuku and tchapalo [17]. Faparusi et al. [18] found the presence of contaminants in the various stages of burukutu liquor production (a locally made alcoholic beverage from millet) and indicated that most of the bacteria survived at low acidity. This observation had been confirmed by other researchers [19-20]. S. cerevisiae which appeared in all the sites could be the predominant fermenter while most of the other microorganisms were there as opportunistic and contaminants from the environment. Studies have shown that the microoraganisms involved in the natural fermentation of cereals are essentially the microflora of the raw materials and equipment [21-22].

The presence of E. coli in the Aboabo and Anloga sample sites indicate a very low level of hygienic conditions of the environment and the individuals involved in the production since the laboratory produced samples did not record E. coli. In Nigeria, Kolawale et al.[19] attributed the presence of $E$. coli to improper sanitary condition during processing of brukutu from water supplies, unsterilized utensils and contaminations by flies.

\section{Spoilage microbes in olewonyo}

A range of microbes can be associated with olewonyo production, but only a few may be able to cause spoilage. As microbes differ in their growth requirements, different beverages support different spoilage microorganisms [1423]. Lactic and acetic acid bacteria are the most common spoilage bacteria found in soft drinks. Their ability to tolerate environments with low $\mathrm{pH}$ is essential for growth in soft drinks. The presence of Leuconostoc mesenteroides, Lactobacillus brevis, L. plantarum, and $L$. acidophilus in this study may be responsible for the spoilage. Microbiological spoilage leads to deterioration of the sensory quality and typically appears as off-flavours, odours and visual changes in the product. In addition to direct spoilage mediated by viable cells [24], carry-over of microbial metabolites from raw materials can lead to indirect spoilage. LAB ferment sugars predominantly to lactate. Depending on the species and growth conditions, sugar catabolism can also lead to formation of ethanol, acetate, formate or succinate [25]. Some strains produce diacetyl, which tastes and smells buttery, and is an unwanted metabolite in soft drinks.

Yeasts are considered as the primary spoilage microbes in carbonated products mainly due to their ability to withstand high carbonation levels. Most species grow in the $\mathrm{pH}$ range 1.5-8.5 [26] and have their growth optimum in the $\mathrm{pH}$ range 3.0-6.0 [14]. Reports indicate that Saccharomyces cerevisiae is the most frequent spoiler of lemonades and fruit juices [27]. It is also reported that brewer's yeasts which are ubiquitous contaminants in a brewery environment may also cause spoilage.

\section{CONCLUSION}

The present study shows that Leuconostoc mesenteroides, Lactobacillus plantarum, L. acidophilus, L. brevis, $L$. fermentatum, Corynebacterium, Saccharomyces cerevisiae, Aspergillus flavus and A. parasiticus are involved or associated in the spoilage of olewonyo. The level of bacteria yeast diversity was found to correlate with the chemical characteristics of olewonyo in terms of moisture content, salt content, and $\mathrm{pH}$. The storage and the environmental conditions under which it is prepared can greatly contribute in prolonging the shelf-life of olewonyo 
beyond the maximum three days. The lab-simulated samples recorded the least microbial load as well as only four (4) of the possible spoilage organisms isolated from the Aboabo and Anloga samples.

\section{ACKNOWLEDGEMENT}

The authors would like to gratefully acknowledge everyone involve in this research especially to the Technicians at the Microbiology Laboratory at the Department of Theoretical and Applied Biology, Kwame Nkrumah University of Science and Technology, Kumasi, Ghana for their guidance and support.

\section{REFERENCES}

[1] J. C. Ogier, V. Lafarge, V. Girard, A. Rault, V. Maladen, A. Gruss, J-Y. Leveau, A. Delacroix-Buchet. (2004). Molecular Fingerprinting of Dairy Microbial Ecosystems by Use of Temporal Temperature and Denaturing Gradient Gel Electrophoresis. Appl. Environ. Microbiol. 70:5628-5643

[2] T. Deak, L. R. Beuchat, (1996). Handbook of Food Spoilage Yeasts. Boca Raton, FL: CRC Press.

[3] F. G. Martley, V. L.Crow (1993). Interactions between non-starter microorganisms during cheese manufacture and ripening. Int. Dairy J. 3:461-483

[4] N. M. Brennan, A. C. Ward, P. F. Beresford, M. Fox, M. Goodfellow, T. M Cogan (2002). Biodiversity of the bacterial flora on the surface of a smear cheese. Appl. Environ. Microbiol.68:820830

[5] G. H. Fleet (2007). Yeast in foods and beverages: impact on product quality and safety. Curr Opin Biotechnol. 18:170-5

[6] G. El-Baradei, D-B Agnes, J-C Ogier 2007. Biodiversity of bacterial ecosystems in traditional Egyptian Domiati cheese. Appl EnvironMicrobiol 73:1248-55.

[7] W. M. El-Sharoud, G. Spano 2008. Diversity and enterotoxigenicity of Staphylococcus spp. associated with Domiati cheese. J Food Prot 71:2567-71

[8] W. M. El-Sharoud (2009). Prevalence and survival of Campylobacter in Egyptian dairy products. Food Res Int 42:62226.

[9] AOAC. Official Methods of Analysis, Association of Official Analytical Chemists, Inc. HII North Nineteenth street suite 210 Arlington, Virginia 22209 USA. 1984.

[10] W. F. Harrigan, M. E. McCance (Eds) Laboratory Methods in Food and Dairy Microbiology, Academic Press, Orlando. 1976.

[11] Food and Drug Administration (1995). Bacteriological Analytical Manual, $8^{\text {th }}$ edition, Association of Analytical Chemists. Arlington, VA. 1995: Chapters 1 and 3.

[12] R. Zvauya, T. Mygochi T, W Parawira (1997). Microbial and Biochemical Changes Occurring During Production of Masvusvu and Mangisi, Traditional Zimbabwean Beverages. Plants Foods for Human Nutrition (Formerly Qualitas plantarum). Springer Science Business Media B.V., Formerly Kluwer Academic Publishers. B.V.Vol. 51. 43-51

[13] C. N. Kunyanga, S. K. Mbugua, E. K. Kangethe, J. K. Imungi. (2009) Microbiological and Acidity changes during the traditional production of kirario: An indigenous Kenyan fermented porridge produced from green maize and millet. African Journal of Food Agriculture Nutrition and Development. 9(6): 1419-1435

[14] K. Lawlor, J. Schuman, P. Simpson, J. Taormina, (2009). In: W. H. Sperber, M. P. Doyle, (eds.) Compendium of the Microbiological Spoilage of Foods and Beverages, Food Microbiology and Safety, pp. 245-283, Springer, New York.

[15] B. Namugumya, C. M. B. K. Muyanja, (2009). Traditional processing microbiology, physicochemical and sensory characteristics of kwete, A Ugandan fermented maize based beverage. African J. Food Agric. Nutr. Develop; 9(4): 1047-1059

[16] L. Sawadogo, H. V. Lei, B. Diawa, D. S. Nielson, P. L. Nioller, A. S. Traore, M. Jakobsen, (2007). The biodiversity of predominant lactic acid bacteria in dolo and pito wort for the production of Sorghum beer. Journal of Applied Microbiology 103 (4):765-777

[17] C. A. Togo, S. B. Feresu, A. N. Mutukumira, (2000). Identification of Lactic Acid Bacteria isolated from opaque beer (Chibuku) for potential use as starter culture. Journal of Food Technology in Africa. 7(3): 93-97

[18] S. I. Faparusi, M. O. Olofinboba, J. A. Ekundayo, (2007). The Microbiology of burukutu beer. Zeitschrift $f$ ur allgemeine Mikrobiologie 13(7): 563-568.

[19] O. M. Kolawole, R. M. O. Kayode, B. Akindayo, (2007). Proximate and Microbial analyses of burukutu and pito produced in Ilorin. Nigeria. African Journal of Biotechnology 6 (5):587-590

[20] O. K. Achi, (2008). Microbiology of "Obiolor" a Nigerian fermented non alcoholic beverage. Journal of Applied Microbiology 69(3): 321-325.

[21] M. J. R. Nout, (1980). Microbiological Aspects of the Traditional Manufacture of Bussa, a Kenyan Opaque Maize Beer. Chem. Mikrobiol. Techno. Lebensm. 1980; 6: 137-142.

[22] W. H. Holzapfel, (2002). Appropriate Starter Culture Technologies for Small-Scale Fermentation in Developing Countries. Int. J. Food Microbiol. 75:197-212.

[23] A. A. Tribst, S. Sant'Ana Ade, P. R. de Massaguer, (2009) Review: Microbiological quality and safety of fruit juices--past, present and future perspectives. Critical Reviews in Microbiology, Vol. 35, pp. 310-339. ISSN 1549-7828; 1040-841X. doi: $10.3109 / 10408410903241428$.

[24] M. Stratford, (2006). Food and Beverage Spoilage Yeasts, In: H. Querol, G. Fleet, (eds.) Yeasts in Food and Beverages, Berlin, Germany: Springer-Verlag, Chapter 11, pp. 335-379.

[25] W. Hammes, C. Hertel, C. (2009). Genus I. Lactobacillus beijerinck 1901, 212AL. In: P. De Vos, G. Garrity, D. Jones, N. R. Krieg, W. Ludwig, F. A. Rainey, K.-H. Schleifer, W. B. Whitman, (eds.). Bergey's Manual of Systematic Bacteriology, 2nd ed. New York, USA: Springer. Pp. 465-513. ISBN 0-387-95041-9.

[26] W. H. Sperber, 2009. Introduction to the, In: W. H. Sperber, M. P. Doyle, (eds.) Compendium of the Microbiological Spoilage of Foods and Beverages, Food Microbiology and Safety, p. 1-39, Springer, New York.

[27] W. Back, 2005. Colour Atlas and Handbook of Beverage Biology. W. Back (ed.). Verlag Hans Carl: Nürnberg, Germany, p. 317 